\title{
Municipal Local Economic Development and the Multiplier effect: Piloting a Community Enterprise Identification Method in South Africa and Namibia
}

Commonwealth Journal of Local Governance

Issue 8/9: May-November 2011

http://epress.lib.uts.edu.au/ojs/index.php/cjlg

\section{Lucienne Heideman}

P3 Project: Partnership-Participation-Progress ${ }^{1}$

South Africa

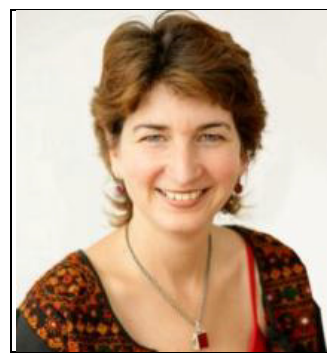

\begin{abstract}
Local Economic Development (LED) is a contested concept in southern Africa, and has become synonymous with delivery of generic job-creation projects, often grant-dependent and unsustainable. Municipal LED has followed this pattern in South Africa since 1994, with little lasting success. Each local economy is unique, and has its own problems and opportunities. The 'Plugging the Leaks" ${ }^{2}$ method recognizes that communities themselves know best how money enters and exits their area. By asking people to analyse their local economy as a 'leaky bucket', the method puts control back in the hands of local people, rather than external experts, and allows them to analyse their own local economy to identify gaps and opportunities for enterprise. By better networking and working collectively to improve their local economy, local communities are able to re-circulate cash internally. This circulation of cash is explained as the local multiplier effect in the workshops.
\end{abstract}

\footnotetext{
${ }^{1}$ Funded by the European Union and the Swedish International Development Agency

2 As developed by the New Economics Foundation. For more information visit <www.pluggingtheleaks.org $>$
} 
A pilot process of running 'Plugging the Leaks' workshops in low income communities in South Africa and Namibia revealed that spending choices in these communities are severely limited in a context where there is no effective welfare state. Therefore, empowerment with this method came from the discovery of collective action and networking, rather than from individual spending choices. Local start-up business tends to be limited to survivalist and copy-cat one-person ventures, and are a last resort when formal employment is absent. In this context collective enterprise offers the necessary empowerment for people to attempt financially sustainable ventures that respond to a gap in the local economy. The pilot project is attempting to show that municipal LED staff can play the role of facilitator for initiating the enterprise-identification process and further mobilise state enterprise support agencies around the locus of LED, without crossing the line between facilitation and implementation of 'projects'.

\section{Introduction}

During 2010 the P3 Project (which focused on local economic development in twenty four municipalities across South Africa, Namibia and Botswana), began piloting a local economic development (LED) tool based on the Keynesian multiplier model or local multiplier effect (LM3). As an innovate approach to community enterprise identification, Plugging the Leaks had been used in South Africa in only two locations, ${ }^{3}$ and was entirely untested in Namibia and Botswana. Evidence based on the initial series of workshops held in two municipal areas of the Western Cape, South Africa and the Erongo region of Namibia is proving its value to municipal LED practice as a viable instrument of policy implementation sympathetic to local conditions. This paper attempts to locate Plugging the Leaks as an LED tool within the policy and socio-economic context of Namibia and South Africa and, based on the initial findings, reflects on the prospects for broader up-take in municipalities across Southern Africa.

\section{The P3 Partnership}

The P3 project is a partnership between four municipal associations. The Association of Swedish Local Authorities and Regions is the lead partner and in southern Africa, where implementation takes place with municipalities, the partners are the South African Local

\footnotetext{
${ }^{3}$ Ncera village in the Eastern Cape, and the Waterloo township in Durban, Kwazulu-Natal.
} 
Government Association (SALGA), the Botswana Association of Local Authorities (BALA), and the Association of Local Authorities in Namibia (ALAN). The three-year project started in early 2009, and is funded by the European Union (75\%) and the Swedish International Development Agency (25\%).

The project aims to support municipalities through providing mechanisms to promote transparency and improved relations between local government and citizens. It does this through the application of a set of tools to improve municipal functions in the areas of LED, Financial Management \& Transparency. The project has offices in all three southern African countries, and works in 24 municipalities spread across the countries. These municipalities form the pilot phase of the project in which tools are tested and developed for further roll-out through the municipal associations.

The P3 project was conceived in three phases. The inception phase involved selection of municipalities, assessment of these, and adaptation of tools to the local context. The second phase was implementation of selected tools, adjustments, evaluation and product design for further dissemination. The final phase is the institutionalisation where partner associations promote further uptake of the results. The LED part of the project is currently nearing the end of the implementation phase, with a project end date of February 2012.

The LED component of the project started from the premise that municipalities impact directly on the business-enabling environment in their locality. Municipalities can facilitate LED by creating the enabling environment that leads to private-sector job creation. Thus the programme was mindful of the contestation of meaning around LED, especially in South Africa, and tried not to create expectations within municipalities that the programme would bring 'projects' to bear. Instead the P3 staff offered municipalities LED tools as systematic processes, aimed at improving the business-enabling environment. If projects emerged along the way, these were not the core focus of the LED endeavour but were added bonuses. Nonetheless some P3 municipal councillors have tried to push for more tangible job-creation projects which satisfy constituents' demands for quick-fix subsidized employment. As a donor-funded programme P3 has had to dispel municipal expectations that it offers grant funding for employment 'projects'. 
P3 offers supply-side LED interventions that build capacity within the municipality to partner civil society and manage economic development within their means. As a donor funded programme it is fairly unusual in its selection of targeted municipalities. Instead of aiming the support at the weakest municipalities, the $\mathrm{P} 3$ project set criteria for selection that sought to attract municipalities with some stability, LED staff in place and the potential to capitalise on satisfactory performance. P3 looked for potential in small to medium municipalities where existing capacity would make it possible for the LED offerings to be absorbed into the institutions. The idea was to help municipalities improve what they were already doing. Inevitably not all the 24 municipalities turned out to be as stable as had been hoped, but the majority kept pace with the programme of activities. The more engaged municipalities have been able to gain a lot of value from the LED tools.

All 24 municipalities were introduced to the LED Roundtable concept which was adapted from work done in Bosnia Herzegovina. An LED discussion forum was not entirely new in South Africa, but was novel in Namibia and Botswana. The P3 Municipalities hold quarterly LED Roundtables with a strong emphasis on business stakeholders, where the agendas include reports on progress in implementing LED tools between meetings and a platform for information sharing.

P3 Municipalities were offered three elective LED tools. Red-tape reduction focused on process or regulatory review, improvement and internal efficiency particularly impacting on business. Business retention and expansion (BR\&E) was designed to develop better feedback loops, partnership formation, recognition and encouragement of responsible business. Municipalities recognised that job retention and creation is more likely to occur through business expansion than by new start-ups, with about $70 \%$ of $\mathrm{P} 3$ municipalities choosing this option. Plugging the Leaks in the local economy was seen as a way of stopping cash outflows and enhancing local circulation of cash within municipal boundaries. Almost all municipalities asked for this option, making it the most popular of the P3's elective tools.

In addition to the elective tools, all municipalities did business-enabling environment surveys at the start of the project to lay down a baseline of qualitative information (Swinburn, Goga 
\& Murphy 2006). The survey will be repeated at the end of the implementation period in June 2011 and will then be able to show changes over time.

\section{What is 'Plugging the Leaks'?}

Plugging the Leaks was developed in 2002 by the New Economics Foundation (NEF). It was initially tested over four years in thirteen low-income communities in the East Midlands of England. Since 2007 it has been tested by international partners in Brazil, Honduras, Israel, Mozambique and South Africa. It has been rated as unusually effective by international partners in various settings and contexts.

The New Economics Foundation is an independent 'think and do' tank that explores alternatives to mainstream economics. At NEF they believe that the problem in low-income communities is not so much what is missing from the local economy, but rather how wisely people utilise what is already there (Pienaar 2010, personal communication 9 Oct).

Plugging the Leaks uses the analogy of a local economy as a leaky bucket. It enables people to identify the in and out-flows of cash, and find local means to plug these leaks. It is based on prioritising local enterprise, and emphasises local value-addition and innovation. It looks for activities with strong multiplier effects, and increases the interconnectedness of elements within a local economy. At its simplest, the local multiplier effect is the observation that the more a unit of currency circulates in a local economy before leaving, the more wealth it creates.

Typically this method identifies ways to stop value leaving the locality, improves the circulation of cash within the local economy, and improves the quality of life of residents. It also reduces the environmental footprint of a local economy as transport is reduced, and is thus a green LED approach. It tends to build community pride in a locality, and improve cooperation among business.

Plugging the Leaks is about interconnectedness in local economies, however using the analogy of the leaking bucket allows communities to engage with concepts of the local multiplier effect without the use of intimidating and exclusionary jargon. The method does not advocate isolation of local economies, which would lead to protectionism. Importsubstitution has a role to play in ensuring greater circulation of cash, but it should not lead to 
reduced choices for consumers, or higher prices, or lower quality. Instead, Plugging the Leaks advocates increased interconnectedness within local economies that increases the local multiplier effect.

Traditional approaches to LED have seen municipalities competing against one another to attract inward investment, seen as a panacea for unemployment. The competition between places can lead to the offering of incentives that outweigh the benefits to local communities. This is often referred to as the "race to the bottom". Municipalities may offer rates rebates, cheap electricity and water, subsidised industrial sites, etc. These lost revenues sometimes outweigh the benefit of the often low quality, poorly paid jobs created locally (Bond 2002). The era of the so-called Washington consensus of export-led growth and ruinous competition has failed to deliver in Southern Africa, and this demands more creative approaches to stimulating economic growth.

Plugging the Leaks is a bottom-up approach to economic development, and does not rely on experts. Experts typically do not live in the area where they plan economic development, so they do not have to live with the consequences of economic decisions (Ward and Lewis 2002). Plugging the Leaks is a method of harnessing local knowledge and garnering people to take action to analyse and intervene in shaping their local economy to suit their needs. It is premised on the notion that local development is enacted by the people concerned, on the basis of their own knowledge, experience and culture (Escobar 1997).

\section{Why 'Plugging the Leaks'?}

Plugging the Leaks as an implementation tool for local economic development falls within the developmental LED approaches rather than the more familiar orthodox approaches (Pieterse 1999). It is a community-based strategy that emphasises working directly with lowincome communities. While the South African government implied support to this kind of strategy as far back as 2002, arguably very little piloting of comprehensive implementation tools, directly working with low-income communities through municipalities, has taken place to date.

Bond noted in 2002 that "sometimes it is crucial to stem the outflow of money from poor areas by encouraging people to buy local, supporting and building periodic markets, funding 
special events and festivals, providing infrastructure using local labour and locally manufactured material, promoting employee training, and networking enterprises of all sizes in the local area" (2002, p. 11). At the time he lamented the residual attraction in government to the more traditional place-marketing, smokestack-chasing and urban-entrepreneurial approaches. Another author states: "While there is growing consensus about what does not work in LED (such as government-led ad hoc projects) there is much less appreciation of 'good practice' in LED” (Rogerson 2010, p. 488). Could Plugging the Leaks be one such good practice? The P3 project argued it could be, and started working toward running Plugging the Leaks workshops in its partner municipalities in 2010.

\section{LED as a Contested Concept in South Africa}

Local Economic Development is a teenager in South Africa. Policy on this priority mandate has been hotly contested, with the first ten years of democracy given over to community development projects with dubious economic sustainability and limited meaningful stakeholder partnership (Hindson \& Vicente 2005).

At its most extreme, the policy community polarised around LED as a form of poverty alleviation with strong state intervention to create jobs directly through projects, as opposed to the facilitation of economic growth through improving the enabling environment. Rogerson has characterised this debate on the meaning of LED in South Africa as the social welfare approach versus the competitive approach (2010, p. 483). For the purposes of sketching the broad policy context in this paper his terminology will suffice. It is important to place the practice of Plugging the Leaks against this policy backdrop as an instrument of policy implementation. Plugging the Leaks can be categorised as a community-based strategy working directly with local-income communities (Pieterse 2000).

The key focus of this paper is anticipating how a broader uptake of the Plugging the Leaks toolkit as a municipal approach to LED might offer a workable method for bringing enterprise development back into the municipal sphere without crossing the line of job creation through projects. The danger is that LED can be perceived as a set of projects all over again, instead of a series of systematic processes or tools to improve the business enabling environment. 


\section{Historical evolution of LED policy}

In 1996 the South African Constitution made local economic development an obligation for local authorities, and in 1998 the White Paper on Local Government introduced the notion of developmental local government and LED as a key mandate. The 2000 Municipal Systems Act legislated municipal LED functions as part of Integrated Development Planning (Rogerson 2010, p. 481). However, studies show that municipalities remained unclear on what LED means, how to organise it, and what to do in practical terms (Meyer-Stamer 2002). Until there is consensus among practitioners in local authorities on what LED is, progress will inevitably be slow (Sibisi 2009).

The poverty alleviation model emphasised strong state intervention and municipalities leading from the front, with LED as a set of municipal projects to create jobs. The social welfare elements of this approach are all too clear. The South African government created a Local Economic Development Fund to support poverty-reducing LED projects in 1999, housed under the national department responsible for local government (Department of Provincial and Local Government (DPLG), renamed the Department of Cooperative Governance and Traditional Affairs (CoGTA) in 2009). After a damning review of the Fund in 2003, the government reconsidered its approach to LED and in 2006 released new guidelines on LED.

Direct funding for community projects had failed to create sustainable enterprises, often due to a lack of consideration for the key question of local markets. Weaning projects off grant funding proved almost impossible, and many talented people found themselves with no market for the goods they were producing. Municipal LED staff found themselves trying to run local projects as businesses, having little or no training in business-related fields to fall back on. "The limited success of LED projects with a welfare focus has undermined the credibility and significance attached to LED by many local authorities" (Rogerson 2010, p. 489).

National oversight of LED and state-funding mechanisms in South Africa are spread across numerous ministries and agencies. This may have created the conditions for contestation of the meaning of LED within government itself. The two key players in the contest for defining LED, leading up to the new guidelines in 2006, were the Department of Provincial 
and Local Government (DPLG) and the Department of Trade and Industry (DTI). Interventions made by the Department of Trade and Industry focused on "competitiveness, comparative advantage, SMME's and co-operatives development; as opposed to DPLG's focus on governance" (Rogerson 2010, p. 484). To date, the fragmentation of support and finance functions for LED present the municipal LED official with an array of confusing choices.

The international trend away from the role of the state in LED, and from direct intervention to 'enablement' where government creates a favourable environment for LED, is the context into which the $\mathrm{P} 3$ project was born. In South Africa shifts in LED practice have been a case of "learning through doing, and even learning from mistakes" (Rogerson 2010, p. 487). By partnering with Botswana and Namibia in the P3 Project, South Africa has a unique opportunity to help these countries not to make the same mistakes in the first democratic decade of their LED experience. The relative LED policy and regulatory vacuum in Botswana and Namibia presents space for sharing of experience.

\section{Emerging LED practice in the context of municipal size}

Although the current policy approach to LED in South Africa is swinging away from projectdriven LED, LED strategies, especially in smaller local authorities, still tend to be project focused (Van de Heijden 2008, in Rogerson 2010):

LED initiatives in smaller centre's tend to be project-based, while those in larger centre's are increasingly focused on creating appropriate institutional market enabling frameworks (Rogerson 2010, p. 485)

In larger metropolitan areas, LED focuses on creating a supportive and competitive business environment, emphasising business sectors or clusters, business retention, red-tape reduction and sometimes investment incentives. In smaller centres, LED focuses on better basic service delivery, public works and SMME development (Rogerson 2010). This may well be why Plugging the Leaks is perceived as an enterprise-development model appropriate for smaller centres, especially those that compete directly with neighbouring larger settlements for a finite pool of cash.

Limited capacities of LED staff have led to smaller municipalities focusing on compliance with statutory requirements rather than proactive management of economic opportunities 
(Lawrence and Hadingham 2008). In general, the smaller the municipality in South Africa, the lower its investment in human resources in the LED section. The positioning of the LED function in the municipal organogram also appears to have a direct bearing on its ability to mobilise municipal departments behind common economic objectives (Provincial Local Economic Development Support Programme Eastern Cape 2005).

Rogerson argues for a differentiated approach to LED in smaller versus larger municipalities. He argues that most municipalities are just "too busy to focus on economic potential because of the imperatives of addressing basic needs" (Rogerson 2010, p. 486). Policies typically use a one-size-fits all approach, which is an inherent weakness of generic policy. It is more the policy instruments that give expression to differentiation, and the P3 project has focused on smaller municipalities for Plugging the Leaks. However, there is no reason why smaller units of targeted communities within larger urban centres should not yield similar results, such as those emerging out of Waterloo Township in Durban where an NEF-supported Plugging the Leaks project is more advanced. The Industrial Development Corporation in South Africa funds Local Economic Development Agencies (LEDAs) as a way of delivering economic development, especially in smaller municipalities where LED competes for municipal resources with pressing issues such as provision of clean water to impoverished communities (Thina Sinako 2007).

\section{LED in Namibia}

In contrast to South Africa, Namibia has a different experience of municipal government and local economic development. The country has a population of under two million compared to South Africa's forty million plus, however Namibia does share some common socioeconomic characteristics with South Africa due to previous links with its neighbour to the south. Since independence in 1990 the policy and regulatory environment for LED in Namibia has not been the subject of intense focus in the way it has been in South Africa. Multiple pieces of legislation have a bearing on municipal development plans in Namibia, which include local economic development without elevating LED to a core municipal mandate. The support environment for LED in Namibia, including that usually occupied by donors, has been under-subscribed until very recently. 
Namibia adopted a White Paper on Local Economic Development in 2009, the production of which was supported by GTZ (German Technical Cooperation). GTZ is also behind the Local Economic Development Agency (LEDA) being set up within the ministry to support municipalities in developing LED strategies and processes going forward. This process is still in its infancy. Namibia inherited much of the land-use planning approaches from its former colonial apartheid era, and consequently faces many of the same spatial legacies confronting South Africa.

The vision for LED in the White Paper on LED in Namibia acknowledges that national efforts are geared towards enhancing the conditions for greater global competitiveness in the country. The White Paper asserts that it is at the local and regional levels that opportunities are identified and harnessed. The document asserts that each local area is different and that initiatives rest on the active involvement of local people and the responsiveness of public and private actors. It does not prescribe any specific action to local players but aims to create a common understanding of regional and local economic development as a concept, and provide practical examples of initiatives which are drawn from local and international LED practices. The White Paper then provides a framework for local and regional development, and adds value to national development initiatives without being prescriptive (GTZ 2008).

\section{Adapting 'Plugging the Leaks'}

At the start of the P3 project, research into different tools was undertaken to select appropriate offerings for the municipalities in the project. The commitment to people development prioritised by the project donors meant that concrete instruments that 'empowered' state and non-state actors in partnership to improve their local economy were attractive. While the term 'empowerment' might be over-used (Cook 1994), it has been an effective label for the longer term social sustainability of actions undertaken in the project which need to remain within the institutional fabric of partner institutions.

The NEF-developed Plugging the Leaks workshops stood out as a unique offering. The other LED tools selected were process-orientated, and did not focus on enterprise identification. Instead they focused on municipalities reaching out to existing business stakeholders to improve the business enabling environment. Plugging the Leaks is different in that it is a 
bottom-up approach that taps into local knowledge to provide analysis of gaps in the market. It pushes LED back in the direction of enterprise development. While this may be dangerous in a context where municipalities still sometimes regard LED as a 'project' or set of 'projects', the more nuanced municipalities are able to draw a clear line where their role as facilitator ends, and that of enterprise support institutions (business services, finance provision etc.) begins.

The method was initially tested over four years in thirteen low-income communities in the East Midlands of England. Some of the examples in the British developed handbook reflected their context, for example illustrations using housing estates familiar to the original domestic audience. These had to be changed for southern African. P3 Process Facilitators tailored the workshop format to take account of local dynamics, including language differences. The overall intention remained the same however, to build economic literacy and empower communities to utilise existing resources toward local enterprise. Donors increasingly expect participation of beneficiaries in development programmes, but very often this participation is merely a means to an end, the end being project efficiency, effectiveness and lower costs. Where there is a more fundamental power shift, the participation becomes the end in itself so that the community or group sets up a process to control its own development (Nelson, N \&Wright, S 1995, p. 1). This was a guiding principle behind the method. However this requires a shift in power between the participants.

NEF were very supportive of P3 interest in their handbook and connected practitioners around the world. Where Plugging the Leaks was being run in the Waterloo township of Durban in Kwa-Zulu Natal (South Africa), a comprehensive programme around the community workshops was set up, including a full-time coach to assist workshop participants to take their enterprise ideas forward to fruition. In Waterloo the programme included a micro-finance organisation ready to back viable business plans with small loans. These two elements of a Plugging the Leaks programme (a coach and micro-finance) required planning support and resources which the $\mathrm{P} 3$ project did not have immediate access to. Nonetheless the potential in the basic approach was clear, and the existence of multiple state agencies tasked with enterprise development and funding in South Africa especially encouraged P3 to test the workshop approach in interested municipalities. 


\section{Preparing for 'Plugging the Leaks' Workshops}

When P3 embarked on running the Plugging the Leaks workshops, a few key goals were drawn from the NEF handbook. P3 hoped to improve economic literacy, encourage local networking and cooperation, identify markets, and create spending impact awareness. Expectations were that each of these objectives would be equally well received.

Workshop preparations took place in a number of stages. The first task was to elaborate the process to P3 partner municipalities so that they might make an informed selection. Municipalities seemed to identify with the problem of competition between settlements for circulation of cash. Discussions around the target audience followed, with some municipalities wanting to involve more established business. However, the NEF noted that established business often tend to bring sceptical voices to bear, and can actually act as a barrier to entry for smaller new business. Municipalities wanting to prioritise existing business were steered in the direction of BR\&E as an alternative to Plugging the Leaks. In the absence of a full-time coach the need to mobilise other entrepreneurial support was evident.

P3 staff worked with municipal LED staff to identify the local players providing support services such as business advice and enterprise finance, and ensured they were briefed and invited to the workshops. A concerted effort was made to set municipalities in the role of facilitator and coordinator of multiple agencies all working toward the same goal of supporting local enterprise. Invitations to participants went out on the letterhead of the municipality, using existing networks and communications channels to reach entrepreneurs and potential entrepreneurs. Not all municipalities were diligent about getting the word out into communities which resulted in varying numbers of participants at workshops. The highest turnout of receptive participants occurred where existing enterprise-support agencies used their database of 'clients' to disseminate the invitation.

In preparation for the first workshops the team of Process Facilitators rehearsed an illustrative story showing the local multiplier effect and the orchestrated bucket demonstrations showing cash flow. The Process Facilitators acquired all the props and rehearsed the bucket sequences with water. A story about a travelling salesman was 
developed to demonstrate the local multiplier effect. The story begins with a travelling salesperson that comes to a town and needs to stay overnight.

The travelling salesperson comes into the local hotel and asks at the reception if they have a room for one night. The hotel owner replies that there is a room available on the fourth floor and offers him the key to go and inspect the room for himself. The travelling salesperson pays a deposit of R100 cash and walks upstairs to go and look at the room. The hotel owner walks into the back office where the plumber has been doing repairs in the hotel, and pays the plumber the R100 note owed for services rendered. The plumber is pleased and upon leaving the hotel pays a woman who rents a room in the hotel R100 he owes her for a jersey she knitted for his son recently. The woman takes the R100 note and gives it back to the hotel owner for the rent she owes. The travelling salesperson comes back down to the reception and explains that the room is not suitable for his needs so he will look elsewhere for accommodation. The hotel owner gives him back his R100 note which he leaves with.

This simple story shows how circulation of a single note of cash leaves value in its wake, increasing each time it changes hands. This story prompts workshop participants to think about the impact their spending choices have on their local economy.

\section{Making Sense of Responses to 'Plugging the Leaks'}

In the first two months of rolling out the first Plugging the Leaks workshops events were held in the towns of Grabouw, Caledon (Theewaterskloof Local Municipality), Napier, Bredasdorp (Cape Agulhas Local Municipality) in South Africa (Western Cape), and in Arandis and Walvis Bay (Namibia). Despite spanning two countries with different languages, cultures and local government systems, the audience response to the approach was similar. The socio-economic profile of the four municipal areas reveal some common characteristics that may go some way toward explaining common responses.

\section{Socio-economic context: Namibia: Walvis Bay and Arandis}

Walvis Bay (meaning whale bay) lies on the western edge of the Namib dessert. The setting is spectacular as the dessert dunes roll out to meet the sea. The town has a deepwater sea harbor which provides its main source of employment. Namport is an important access point for landlocked SADC countries like Zimbabwe and Botswana, and also services oil rigs positioned off the Angolan cost to the north (Walvis Bay Biodiversity Report 2008).

The main exports are diamonds, minerals, fish, livestock and their by-products. These are exported largely to South Africa and the EU. The principle imports are food and beverages, 
vehicles and machinery. The economy of Namibia is heavily dependent on its natural resources: diamonds, uranium, fish, wildlife and marine resources. This lack of diversification out of the minerals/energy complex places it in a precarious position. Walvis Bay does however benefit from a more diversified local economy than most in Namibia as it has comparatively significant business, industry and tourism sectors (2003 Walvis Bay Local Council).

The small town of Arandis lies 94km inland from Walvis Bay in the Namib dessert. It was created in 1976 by the Rossing Uranium Mine to settle the workforce. The entire town was owned and run by the mine until 1992, when it was given to the Namibian government on independence from South Africa (Hoadley, Atkinson, Limpitlaw \& Tarr 2005).

Unemployment in Arandis and Walvis Bay stands at 34\% (Census 2001). ${ }^{4}$ Fifty percent of Namibians are estimated to live below the poverty line, and income distribution in Namibia is highly unequal. Ten percent of households with the highest income account for almost half the total income, the GINI coefficient for Namibia is 0.6; and unemployment, poverty, HIV/AIDS and gender inequality are prioritised as key development issues in Namibia.

Walvis Bay has an estimated population of 60,000 (Census 2001), while Arandis has an estimated population of 6,000 and Namibia has a total population of 1.83 million. Walvis Bay and its neighbour Swakopmund are the largest urban centres outside the capital, Windhoek, and they both fall within the Erongo region, which had a population of 107,663 at the 2001 Census. Arandis is heavily dependent on the Rossing Mine and mineral deposits, and suffers from lack of economic diversification. Scarcity of water is also a major constraint, and water has to be piped over ground across the dessert from the coast to supply the large mine. Arandis is an outlying mining community that struggles to compete with its larger neighbours on the coast, namely Walvis Bay and Swakopmund (Hoadley et al. 2005).

Household income in the Erongo region which covers both Walvis Bay and Arandis, in 2001 , was made up mostly of salaried/waged employment (67\%), with only $8 \%$ of income derived from self-employment and business income (2006 Central Bureau of Statistics,

\footnotetext{
${ }^{4}$ Both Namibia and South Africa last released reliable Census data in 2001. While these datasets are out of date,
} they are at least universal and therefore comparable. 
National Planning Commission, Windhoek). Unfortunately the census in Namibia does not break down the sectors from which salaries and wages are derived.

\section{Western Cape, South Africa: Theewaterskloof and Cape Agulhas}

The municipality of Theewaterskloof is made up of numerous small towns and their surrounding rural hinterland. The key towns are Caledon, Grabouw, Riviersonderend, Villiersdorp, Genadendal, Greyton and Bot River. The total population is around 107,000 (Theewaterskloof LED Strategy 2009).

The area is within 1.5 hours drive from Cape Town along the N2 road and is separated from the Cape peninsula by a mountain range. The local economy of Theewaterskloof is based mainly on agriculture, followed by trade and community services. The tourism sector is significant, and is captured under 'trade' in terms of Census data. Unemployment - as narrowly defined in census data - shows the figure for Theewaterskloof at $11.6 \%$, which has increased steadily since 2001. The largest number of jobs is in the agricultural sector, although many are seasonal as the area is centre for fruit-growing, particularly apples. At 2001, 52\% of households in Theewaterskloof earned below R 1,600 (US\$ 192) per month, (Theewaterskloof LED Strategy 2009).

The municipality of Cape Agulhas further up the coast from Theewaterskloof is also made up of numerous small towns and their surrounding rural hinterland. The key towns are Bredasdorp, L'Agulhas, Napier, Arniston and Struisbaai, with a municipality population of 27,000 (Cape Agulhas LED Strategy 2009). The area is within 2 hour's drive from Cape Town. The local economy of Cape Agulhas is based on trade, followed by community services and agriculture. The tourism sector is significant, and is captured under 'trade' in terms of Census data. Cape Agulhas is the southern-most point in Africa, but is not particularly well developed for its tourism potential.

Unemployment as narrowly defined in census data shows the figure for Cape Agulhas at $8 \%$, which has also increased since 2001. The largest number of jobs are in the trade sector. Household income in the Cape Agulhas at 2001 was made up mostly of salaries and wages $(30 \%)$, with $3.2 \%$ of people self-employed and only $0.3 \%$ of people employers. For $66 \%$ of the sample, work status figures are not applicable (unemployed or not participating in the 
economy). At 2001, 44\% of households in Cape Agulhas earned below R 1,600 per month (US\$ 210a low-income wage (Cape Agulhas LED Strategy 2009).

\section{Contextual south-south characteristics setting it apart from the north}

All four of the P3 municipal areas where Plugging the Leaks workshops were first run suffer from high levels of unemployment and significant poverty. Inequality inherited from the apartheid legacy which both regions share have endured in the form of race-class correlations:

The inherent tensions between the public and private sectors are compounded by the need to transcend the apartheid legacy of a largely white-owned and controlled private sector and a predominantly black public sector (Rogerson 2010, p. 488).

Socio-economic challenges are not limited to the legacy of racism. Neither South Africa nor Namibia offers an effective social welfare net for people living below the poverty line. Unemployment insurance pays out for a number of weeks depending on the number of years contributed to the system, leaving the unemployed without income within 6 months. No universal income grant exists in either country, although there has been unsuccessful lobbying for such a grant in both South Africa and Namibia ${ }^{5}$. Namibia has a Social Security Commission under the Ministry of Labour working on proposals to improve the system, although the country lags behind South Africa.

Poverty is not limited to the unemployed in either country. As well as low wages implied by low average household incomes, many economic survival strategies involve informal sector activities, or the so-called 'second economy', which is particularly vibrant in South Africa. Profiles of workshop participants revealed that local start-up business tend to be limited to survivalist and copy-cat one-person ventures, and were a last resort when formal employment was absent. Many small scale entrepreneurs complained during workshops of a lack of markets for their goods, a complaint symptomatic of inadequate prioritisation of local demand when selecting economic activity. Workshop participants explained that when they found themselves out of wage employment, they drew on their existing skills and talents hoping that sustainable enterprise would follow. Numerous enterprise support agencies such as the Elgin Foundation and the Western Cape Provincial Government's Red Door

\footnotetext{
5 The Basic Income Grant (BIG).
} 
programme complain that one of their biggest challenges is to get potential entrepreneurs to analyse local markets first and respond strategically.

P3 workshop audiences were largely made up of people who worked in the second economy because they had no wage employment opportunity. Most would prefer wage employment and were forced into the second economy by necessity rather than active choice. This condition, when combined with an inadequate social welfare system, has meant that most workshop participants felt excluded from the first economy and had very little regular reliable cash income. This is the most likely explanation for the most disappointing aspect of the audience traction on Plugging the Leaks: failure to fully realise the impact of individual spending choices as a local multiplier effect. While the travelling salesman story got the message across in terms of keeping money circulating within a local economy, the disempowerment of people excluded from the cash economy was clear as the comparatively limited number of spending choices made became obvious. Inequality in both Namibia and South Africa is staggering, South Africa having one of the highest GINI coefficient in the world: 0.72 in 2005 (Stats SA) (0 represents total equality and 1 total inequality). Namibia stood at 0.6 for 2005 .

\section{Limited individual spending choices}

The generic strength of the Plugging the Leaks method is threefold: identifying gaps in local markets, changing spending patterns, and encouraging networking and collaboration for competitiveness. In the pilot workshops in Namibia and South Africa, two of the three objectives were highly successful: analysing markets and networking. From a resident perspective, the workshops did not yield the level of engagement and traction on individual spending choices as in England. This may be explained by the lack of social welfare funding, which leaves low-income communities with less cash and therefore fewer direct spending choices to be made. Instead, participants latched onto the gap/market analysis aspects as a way of finding an income. High unemployment rates leads to survivalist businesses in southern Africa, the vast majority of which statistically never expand to employ more than one person (Devey, Skinner \& Valodia 2003). In places like the UK it is arguably possible to survive on social welfare, taking away some of the impetus to start an enterprise out of desperation. 
The changing of spending patterns was received with less enthusiasm possibly due to the limited cash spending choices available to workshop participants that were commonly engaged in survivalist businesses. Nonetheless, the value of Plugging the Leaks workshops in South Africa and Namibia is that is showed that LED need not depend on large investment from outside a local economy. It shifts the focus from the supply to the demand side of local economics, showing that whole communities as consumers can contribute to LED by supporting local businesses. But how local is local? In Namibia, South Africa is seen as local, so there are degrees of "localness".

\section{How local is local?}

By encouraging buying local, P3 opened up a discussion about different levels of 'localness' and participants asked questions about chain-stores versus locally-owned franchises. A kind of local-value hierarchy started to emerge out of the collective analysis. The complexity of calculating the value of local procurement in a workshop made it impossible to explore in more detail at the time, but the NEF does offer tools for organisations to calculate their impact. Ideally P3 should also be running this in municipalities and reviewing procurement policies and procedures.

The localness question also opened up potential xenophobia in the very first workshop in Grabouw, with 'Insider-Outsider' dynamics emerging. Participants pointed to examples of successful Somali or Chinese shopkeepers in the community, who work long hours and offer low prices, undercutting other local shops. The issue is how communities and local business people deal with this situation. Do they drive them out (xenophobia) or emulate the survival strategies that cooperation offers? Placing value on 'localness' can quickly cast a shadow of 'us' and 'them', or 'insiders' versus 'outsiders'. While it might be encouraging to see how race is less an issue in communities in South Africa than ever before, xenophobia is a new division which threatens some areas where workshops were held. This required skilled facilitation to manage crowd sentiment and debunk the notion that foreigners don't contribute to local economies.

\section{Finance and facilitation support}

In terms of financing, a comprehensive approach is needed to enterprise development including a variety of stakeholders and access to micro-finance; stakeholders are generally 
regarded as parties who are affected or can affect actions and policies (Nelson, N \& Wright, S. 1995, p. 5).

How funding comes into a community for enterprise development is important. Grant funding can undermine sustainable business development, as happened with the LED Fund set up in the late 1990s in South Africa, where cooperative projects mostly folded when grant money was exhausted. Projects never became economically viable because they were oversubsidised with 'free' money, and sometimes included too many beneficiaries. Individuals who take commercial loans subject to market conditions often have to 'go it alone', working hard to pay them back with interest. This increases ownership and commitment by introducing the element of risk, whereas grant funds used for private goods can distort the market, and lead to unfair competition between enterprises (Philips 2000).

Once workshop participants have identified needs and come up with ideas during the Plugging the Leaks workshops, they need support to plan and realise their ideas. Facilitation and support are essential at this stage in terms of connecting them to resource organisations and people that can provide skills training, coaching and micro-finance. Mediating and brokering to reduce barriers is also valuable. The role of coach is therefore part of the method developed by the NEF. The P3 project did not have the resources to provide a coach for each of the twenty four municipalities in the programme, and therefore had to explore alternative methods for support. This has culminated in two questions. Can municipalities change the way LED officials work to incorporate coaching activities for enterprise development and, relating to the history of LED policy development in South Africa, can municipalities facilitate enterprise development without becoming project implementers?

From the piloting of Plugging the Leaks workshops in South Africa and Namibia it can be concluded that it is viable to build groups of passionate, aspiring entrepreneurs to support each other and find resource organisations and mentors for themselves. For example, groups of people who met at the workshops for the first time have started buying goods together from big wholesalers to get better prices. Utilising economies of scale is a very simple action that greatly increases their efficiency and forms a basis for understanding competitiveness in a more nuanced way. This evolution of cooperation has lead in the direction of revitalised 
business chambers in some towns, and even the mooting of business clusters in others. Although the tools are in the early days of implementation, the positive responses point to significant potential of Plugging the Leaks in a myriad of different contexts. P3 staff occasionally encountered more established business people at the workshops who were sceptical about the method, but they were managed by grouping sceptics together so as not to disrupt other break-away groups.

The Plugging the Leaks approach calls for talented facilitators that are able to guide participants in a fashion that enables rather than dictates; the method is challenging and needs to be managed carefully. It became clear in the first workshop that the 'plugs' identified by groups were only as good as their 'leaks' in the sense that analysis has to be specific and disaggregated in order to contain the seed for concrete solutions. During the group work it also became obvious that if the leaks were not specific, and within the control of the participants, the proposed plugs would be compromised. For example, a leak identified in one group was crime; this was too generic and needed to de disaggregated before any useful plug could become evident. Much clearer leaks - like the lack of a local dry-cleaner yielded much clearer plugs.

\section{Measuring success through change}

Perhaps the greatest change after each workshop was awareness of markets. Participants seemed to develop a new understanding of the importance of identifying markets before starting a business. The norm in low-income communities is for copy-cat businesses, people see others succeed and start a similar business thereby saturating the market, resulting in survivalist businesses that lead a perilous existence. Understanding markets can lead to more financially sustainable businesses that match goods and services with real market gaps. Enterprise support agencies present at the workshops commented on the strength of the method in raising market awareness.

The second visible change was empowerment through joint action, and a new understanding of competitiveness. Participants quickly embraced action-planning in groups, and resolved to follow-up using their own initiative. They also saw the need for collective cooperation in activities like bulk-buying, advertising and referral networks, where small businesses support each other. This revealed a new understanding of competitiveness being not about individual 
competition leading to winners and losers, but rather about cooperating for collective benefit. The method lends itself toward community enterprise because of its structure of collective analysis and problem solving.

Many participants left the workshop feeling passionate about developing their dreams, and inspired by the opportunities which working together offered. The challenge however is to sustain this passion. While the facilitation approach deliberately broke down the perceptions that external forces held the answers and/or resources to solve participants economic problems, the dissolving of the conceptual barriers leading to expressions of 'empowerment' may be temporary. Empowerment implies that "some can act on others to give them power or enable them to realise their own potential" (Nelson and Wright 1995). This leads to the question: can development practitioners effectively transfer power in a workshop without addressing longer term structural power relations outside the workshop event? Developing participants' confidence and abilities may be temporary, and the sense of 'empowerment' reported illusory.

Participants reported feeling empowered by being inspired to take the initiative rather than waiting for a solution to come from elsewhere. This is particularly significant in rural areas, where communities may otherwise become dependent on the larger cities as a source of income, rather than create value locally. The workshops encouraged people to look inward, find value in their familiar surroundings, and take control of the sphere that lies within their influence. If facilitated skilfully, this process can be empowering, and for the long-term unemployed, empowerment can be fundamentally life-changing. Treating local people as experts in understanding their economy offers a break from the all-too familiar donor/grant dependent syndrome which exists in southern Africa. However, the phenomenally high levels of inequality in both Namibia and South Africa mean that power relations in these societies mitigate against the poor participating in the formal economy. Changing these structural power relations is an enormous task not achieved through a few workshops.

Municipal officials like the LED Managers did report benefits from the workshops, being exposed to the daily challenges of SMME's during the P3 workshops was novel. Business stakeholders interacting directly with municipalities in South Africa and Namibia tend to be the larger established businesses, which may have a different set of challenges. 
Municipalities showed their potential to play the role of facilitator and coordinator of multiple agencies for enterprise support, and their relationships with locally-present organisations were valuable in setting up workshops. While the Constitution of South Africa casts municipalities in a facilitator role with regards to development and LED, the mechanics are not well developed or understood. Sustaining the network of support providers has proved a challenge in the municipalities, and the enthusiasm has waned somewhat. Without continuous encouragement the old habits return, and the sense of empowerment is lost.

The character of each Plugging the Leaks workshop was unique; something which underscores the notion that LED is about finding local solutions to local problems. The potential in the method is evident, the challenge seems to be in finding resources for sustained action. For municipalities the potential for changing the way LED officials work with communities to facilitate enterprise is exciting, and at the same time the boundaries between facilitation of processes and implementation of projects is a dangerous line that municipalities in South Africa have crossed before.

\section{Prospects for 'Plugging the Leaks' as a Municipal Application of LED in Southern Africa}

In the absence of networks and little interaction between the local authority and the private sector, the local authority interprets its role as a participant in, rather than facilitator for LED, adopting an ad hoc project-based approach (Sibisis 2009). Plugging the Leaks offers a model for this facilitation of stakeholders that holds considerable promise, but the resources required for sustained action to keep beneficiaries buoyed beyond the workshops (such as full-time enterprise coaches) may be too onerous for municipalities. In addition, cooperation between participants such as collective procurement (buying inputs) requires a level of trust between and across social divisions that cannot be assumed.

"Deep divides remain between predominantly white and conservative business interests and the local authority, which are not conducive to partnering for effective LED strategies" (Rogerson 2010, p 486). This emerged in Namibia as well as South Africa during the pilot Plugging the Leaks workshops. Throughout much of southern Africa, the private sector has either been "left out or has chosen not to be involved as a result of the mutual suspicion 
between the public and private sectors that makes dialogue between the two groups extremely difficult. The public sector believes business is anti-poor and business believes that government is welfarist and anti-profit in its outlook" (Rogerson 2010, p. 488). The P3 Project has used Business Retention \& Expansion (BR\&E) as a tool targeted at more established businesses, and Plugging the Leaks more targeted at the 'second economy' and community groupings as aspirant entrepreneurs. Plugging the Leaks is a more broad-based, bottom-up approach than BR\&E, but empowering people to embrace a bottom-up approach is not without its critics. Rowlands argues that the bottom-up concept can be used to perpetuate and disguise continued top-down attitudes because 'empowerment' is initiated by those who have power over others, and continue to exercise that power over others. The privileged development workers or donors leave the workshop as they arrived. Thus there is no real transfer of power, only the illusion (Rowlands 1992, p. 52, quoted in Nelson \& Wright 1995). Using the distinction between 'power to' and 'power over', it becomes apparent that while any group or individual maintains 'power over' another group or individual, there has been no complete transfer of 'power to'. At best there has been a diluting of that power, which was perhaps never theirs to give away. Nelson and Wright suggest addressing this problem by "institutionalising processes whereby those with newly acquired 'power to' can negotiate with those with 'power over' in the community and in agencies in ways which are 'unpickable' and sustainable when the outsider researcher or development worker has left” (1995, p. 13).

What then have participants learnt from Plugging the Leaks that is difficult to undermine or reverse? Interestingly, BR\&E steering groups in P3 municipalities have watched Plugging the Leaks groups with interest and even envy in places like Cape Agulhas, and are being pushed to "up their game" and to co-operate more effectively as established business organisations, better emulating mobilised and internally networked communities running with Plugging the Leaks.

The emphasis Plugging the Leaks places on local knowledge instead of external 'experts' is perhaps its greatest value to southern African municipalities looking for meaningful participatory LED strategies. Participation as a transformative rather than an instrumental approach is increasingly required by donors, even if only to deflect criticism of dependence 
in donor-beneficiary power relations. As a concrete tool to harness 'indigenous' knowledge, Plugging the Leaks is accessible to skilled development workers. The conditions "under which people may decide to 'disclose' their 'knowledge', and make their needs explicit, are very difficult to create" (Novellino 2003, in Pottier, Bicker, and Sillitoe 2003). The tools offer a systematic means to create the conditions for harnessing untapped knowledge to solve contextual problems in workshop situations, and through continuous coaching afterwards. However, can they create long-term change in the fabric of society in which beneficiaries are located? Surely a critical mass is required before a more fundamental transformative shift can occur?

Rose (2004) and others have argued that voluntary policy transfer occurs through various processes of copying, emulation, hybridisation or inspiration across contexts (Rose 2004, Dolowitz \& Marsh 2000, Evans \& Davies 1999, Stone 1999, Evans 2004). Rose's concept of lesson-drawing as a method of learning from past and/or extra-organisational experiences, emphasising the role of the bureaucrat and the programme itself in the process of policy learning in developed countries, underlines how policy as received wisdom without concrete instruments for implementation, such as LED policy in South Africa and Namibia, is incomplete.

Rogerson argues that to build competitive local economies in South Africa, LED officials need more effective analytical tools, including accurate economic data (2010). The NEF argue that such quantitative data do not provide the full picture, and analytical tools need to be placed in the hands of local "experts"; the people who live with the consequences of economic choices on a daily basis. This emphasis on people at the centre of economic development sits well in southern African where solutions from external "experts" have yet to yield sustainable economic growth. Municipalities in South Africa have struggled to make sense of what statistical economic data exists. By 2008 most municipal Integrated Development Plans in South African municipalities used an economic profile based on the 2001 Census which is both outdated and ill-focused on individuals as the unit of analysis rather than enterprises (Rogerson 2010). Centrally managed sectoral data in Namibia is not effectively disaggregated and is also out of date. 
The Industrial Development Corporation ${ }^{6}$ in South Africa (IDC) notes that LED projects have often failed due to insufficient involvement of local people as participants and beneficiaries. Rather than owners of projects, locals have been relegated to being workers or labourers (Rogerson 2010). This points to a lack of 'empowerment' of local beneficiaries, a critical factor for longer term sustainability. Plugging the Leaks is based on local empowerment as the primary driver of initiative toward community enterprise. Rogerson argues that the need to leverage support for community empowerment is critical to unleash local creativity and innovation: "Advocating the expansion of local multipliers to assist the second economy is a logical policy foundation for future support of the second economy" (Rogerson 2010, p. 493). He advocates for pursuing interventions aimed at the second economy, which is where Plugging the Leaks seems to work best.

While Plugging the Leaks has been delivered primarily through non-governmental and community-based organisations around the world to date, it offers the promise of institutionalising policy instruments for the local state to work directly with low-income communities in the future, assuming resources are channelled into wider implementation. The exact institutional architecture of delivering Plugging the Leaks through municipalities requires some work, but it is not inconceivable that municipalities employ enterprise coaches trained in the approach to give real expression to their mandate to better facilitate and coordinate development within a locality. Alternatively, existing LED staff could be trained in the continuous coaching method, leaving 'unpickable' skills in enduring institutions of government.

\section{References}

Bond, P. 2002, 'Local Economic Development Debates in South Africa' in Municipal Services Project Occasional Paper Series Number 6, February 2002. International Development Research Centre: Kingston Ontario

Cape Agulhas Local Municipality, 2009. Local Economic Development Strategy. Bredasdorp

Central Bureau of Statistics, 2006 Namibian Household Income and Expenditure Survey 2003/2004. National Planning Commission: Windhoek

6 The IDC is a key state-funded body that has set up Local Economic Development Agencies throughout South Africa as special-purpose vehicles for implementing all kinds of economic development projects in municipal boundaries. 
Cook, J. 1999, 'Empowering people for sustainable development' in Fitzgerald, P. McLennan, A and Munslow, B. Managing Sustainable Development in South Africa. Oxford: Oxford University Press.

Devey, R., Skinner, C. \& Valodia, I. 2003 Informal Economy Employment Data in South Africa: A critical analysis. TIPS and DPRU Forum: Johannesburg

Escobar, A 1997, 'The making and unmaking of the Third World though development', in Rahnema, M. and Bawtree, V. (eds) The Post-Development Reader. Zed Books: London

GTZ 2008 (German Technical Cooperation), LED White Paper Namibia. Urbanet Online Library

Hindson, D. and Vicente, V. 2005 Whither LED in South Africa? A Commentary on the Policy Guidelines for Implementing Local Economic Development in South Africa Paper South African Regional Poverty Network: Pretoria

Hoadley, E.M., Atkinson, D., Limpitlaw, D. and Tarr, J. 2005, Arandis Socio-Economic Baseline Study. A report commissioned by The Town Council of Arandis, The Rossing Foundation and Rossing Uranium Ltd. Namibia

Lawrence, F \& Hadingham, T, 2008, Decentralisation and the challenge of institutionalizing local economic development: Some practical insights from the South African experience, @local. glob 5. Delnet Programme International Labour Organisation: Turin

Meyer-Stamer, J. 2002, Current challenges for local economic development in South Africa: Experience from Mpumalanga. Report for GTZ (German Technical Cooperation), South Africa Office: Pretoria.

Nelson, N \& Wright, S (eds). 1995. Power and Participatory Development Theory and Practice. Intermediate Technology Publications: London

Philips, D. 2000. Implementing the market approach to enterprise support: A comparative analysis of matching grant schemes. World Bank: Washington

Pieterse, E. 1999, A Framework to Link LED to Anti-poverty Strategies. Isandla Institute. Department of Constitutional Development: Pretoria

Pottier, J., Bicker, A., \& Sillitoe, P. 2003. Negotiating Local Knowledge: Power and Identity in Development. London: Pluto Press

Provincial Local Economic Development Support Programme, 2005. Municipalities and LED: Consolidated Report on the Eastern Cape. Delegation of the European Commission in South Africa: Pretoria

Republic of Namibia 2008. Regional and Local Economic Development. LED White Paper. Windhoek.

Republic of South Africa 1996. Constitution. Pretoria

Republic of South Africa 1997 White Paper on Local Government. Pretoria

Republic of South Africa 2000 Municipal Systems Act. Pretoria

Rogerson, C.M 2010 'Local Economic Development in South Africa: Strategic Challenges' in Development Southern Africa Vol. 27, No. 4, October 2010. Routledge: Pretoria

Rose, R. 2004 At The Interface Between Theory and Practice - Policy Transfer and Lesson-drawing (Learning From Comparative Public Policy: a Practical Guide) Routledge: London

Sibisi, S, 2009 'Brushing against the grains of history: Making local economic development work in South Africa', In Ngubane, J (Ed.), Local Economic Development. DBSA Working Paper Series No.2: Halfway House Johannesburg

Swinburn G., Goga, S. and Murphy, F. 2006 Local Economic Development: A Primer. Developing and Implementing LED Strategies and Action Plans. The World Bank: Washington

Theewaterskloof Local Municipality, 2009, Local Economic Development Strategy. Caledon 
Thina Sinako 2007, Report on Investigation into Institutional Location and Roles of Local Economic Development Agencies (LEDA's). Local Economic Development Support Programme in the Eastern Cape Province. Delegation of the European Commission in South Africa: Pretoria

Walvis Bay Biodiversity Report 2008. Local Action for Biodiversity Project. Vlaeberg

Walvis Bay Local Council 2003. Local Economic Development Strategy 2003 - 2008. Namibia: Walvis Bay

Ward, B and Lewis, J 2002. Plugging the Leaks: Making the most of every pound that enters your local economy. New Economics Foundation: London. 